Volume 1, Nomor 1, Maret 2019, pp 1-14. Copyright (C) 2019 JAFTA, Program Studi Magister Akuntansi, Fakultas Ekonomi, Universitas Kristen Maranatha.ISSN: 2654-4636| E-ISSN: 2656-758X

http://journal.maranatha.edu/Jafta

\title{
Pengaruh Leverage, Likuiditas, dan Ukuran Perusahaan Sebagai Variabel Moderasi Terhadap Kualitas Laba
}

\author{
Elyzabet Indrawati Marpaung \\ Universitas Kristen Maranatha \\ elyzabetmarpaung@gmail.com
}

\begin{abstract}
The purpose of this research is to determine the effect of leverage, liquidity, firm size on earnings quality and want to test firm size as a moderating variable on influence of leverage and liquidity on earnings quality. Firms as population come from mining firms listed on Indonesia Stock Exchange in 2014-2016. Firms as sample are taken from the population by using simple random sampling. The method of data analysis used is regression model. The result of this study indicate leverage and liquidity have negative effect on earnings quality. Firm size is able to moderate on influence of leverage and liquidity on earnings quality.
\end{abstract}

Keywords : Earnings Quality, Leverage, Liquidity, Firm Size

\begin{abstract}
Abstrak
Tujuan dari peneltian ini adalah untuk menentukan pengaruh leverage, likuiditas, ukuran perusahaan terhadap kualitas laba dan ingin menguji ukuran perusahaan sebagai variabel moderasi pada pengaruh leverage dan likuiditas pada kualitas laba. Populasi adalah perusahaan pertambangan yang tercatat di Bursa Efek Indonesia periode 2014-2016. Sampel adalah perusahaan yang diambil dari populasi menggunakan simple random sampling. Metode analisis data yang digunakan adalah model regresi. Hasil penelitian menunjukkan bahwa leverage dan likuiditas memiliki pengaruh negatif terhadap kualitas laba. Kualitas laba dapat memoderasi pengaruh leverage dan likuiditas terhadap kualitas laba.
\end{abstract}

Kata Kunci : Kualitas Laba, Leverage, Likuiditas, Ukuran Perusahaan

\section{PENDAHULUAN}

Pernyataan Konsep Akuntansi Keuangan No. 1 (SFAC No. 1) menyatakan bahwa pelaporan keuangan harus menyediakan informasi tentang kinerja keuangan perusahaan selama suatu periode. Dalam SFAC No. 1, menyatakan bahwa kualitas laba yang lebih tinggi memberikan lebih banyak informasi tentang fitur kinerja keuangan perusahaan relevan dengan keputusan spesifik yang dibuat oleh pembuat keputusan tertentu (Dechow et al, 2010).

Kualitas laba merupakan aspek penting dalam mengevaluasi kesehatan keuangan entitas, namun investor, kreditur, dan pengguna laporan keuangan lainnya sering mengabaikannya. Kualitas laba mengacu pada kemampuan laba yang dilaporkan untuk mencerminkan laba sebenarnya perusahaan, serta kegunaan laba yang dilaporkan untuk memprediksi laba masa depan. Kualitas laba, 
juga mengacu pada stabilitas, persistensi, dan kurangnya variabilitas dalam laba yang dilaporkan (Bellovary et al., 2005).

Kualitas laba dalam laporan keuangan penting untuk diperhatikan karena jika kualitas labanya rendah, artinya laba yang dilaporkan tidak sesuai dengan kinerja perusahaan yang sesungguhnya, maka hal ini dapat menyesatkan para pengambil keputusan (Kurniawati, 2017).

Banyak faktor yang mempengaruhi kualitas laba seperti implementasi IFRS (Ahalik dan Hardy, 2015), leverage (Ahalik dan Hardy, 2015; dan Fauzi dan Pituringsih, 2015) kepemilikan institusional (Ahalik dan Hardi, 2015; Darabali dan Saitri, 2016; Kartina dan Nikmah, 2011; dan Kurniawati, 2017), kepemilikan manajerial (Darabali dan Saitri, 2016 dan Kartina dan Nikmah, 2011), komite audit (Darabali dan Saitri, 2016), Investment Opportunity Set (Warianto dan Rusiti, 2014), struktur modal (Warianto dan Rusiti, 2014), ukuran perusahaan (Reyhan, 2014 dan Warianto dan Rusiti, 2014 dan Kusumawati dan Wardani, 2018), dan likuiditas (Warianto dan Rusiti, 2014)

Mengingat banyaknya faktor yang mempengaruhi kualitas laba, maka dalam penelitian ini hanya diuji beberapa faktor saja. Beberapa faktor yang dimaksud yaitu leverage (DER), likuiditas (CR), dan ukuran perusahaan (LOGTA). Berbagai penelitian terdahulu telah dilakukan untuk mengkonfirmasi hubungan antara ketiga variabel ini dengan kualitas laba. Meski demikian, ternyata hasilnya masih memperlihatkan ketidakkonsistenan antara satu penelitian dengan penelitian lainnya (lihat Tabel 1). Tabel 1. Ketidakkonsistenan Hasil Penelitian Terdahulu sebagai berikut :
Tabel 1. Ketidakkonsistenan Hasil Penelitian Terdahulu Mengenai Ketiga Faktor Yang Mempengaruhi Kualitas Laba

\begin{tabular}{|c|c|c|c|}
\hline $\begin{array}{c}\text { Nama } \\
\text { Peneliti }\end{array}$ & Leverage & Likuiditas & $\begin{array}{c}\text { Ukuran } \\
\text { Perusahaan }\end{array}$ \\
\hline $\begin{array}{l}\text { Ahalik dan } \\
\text { Hardy }(2015)\end{array}$ & Berpengaruh & $\begin{array}{l}\text { Tidak } \\
\text { Diteliti }\end{array}$ & Tidak Diteliti \\
\hline $\begin{array}{l}\text { Fauzi dan } \\
\text { Pituringsih } \\
(2015)\end{array}$ & Berpengaruh & $\begin{array}{l}\text { Tidak } \\
\text { Berpengaruh }\end{array}$ & Tidak Diteliti \\
\hline $\begin{array}{l}\text { Darabali dan } \\
\text { Saitri (2016 }\end{array}$ & $\begin{array}{l}\text { Tidak } \\
\text { Berpengaruh }\end{array}$ & $\begin{array}{l}\text { Tidak } \\
\text { Diteliti }\end{array}$ & Tidak Diteliti \\
\hline $\begin{array}{l}\text { Reyhan } \\
\text { (2014) }\end{array}$ & $\begin{array}{l}\text { Tidak } \\
\text { Diteliti }\end{array}$ & $\begin{array}{l}\text { Tidak } \\
\text { Diteliti }\end{array}$ & Berpengaruh \\
\hline $\begin{array}{l}\text { Warianto dan } \\
\text { Rusiti (2014) }\end{array}$ & $\begin{array}{l}\text { Tidak } \\
\text { Diteliti }\end{array}$ & $\begin{array}{l}\text { Berpengaruh } \\
\text { Negatif }\end{array}$ & $\begin{array}{l}\text { Berpengaruh } \\
\text { Negatif } \\
\text { signifikan }\end{array}$ \\
\hline $\begin{array}{l}\text { Darabali dan } \\
\text { Saitri (2016) }\end{array}$ & $\begin{array}{l}\text { Tidak } \\
\text { Diteliti }\end{array}$ & $\begin{array}{l}\text { Tidak } \\
\text { Diteliti }\end{array}$ & $\begin{array}{l}\text { Tidak } \\
\text { Berpengaruh }\end{array}$ \\
\hline $\begin{array}{l}\text { Kurniawati } \\
\text { (2017) }\end{array}$ & $\begin{array}{l}\text { Tidak } \\
\text { Diteliti }\end{array}$ & $\begin{array}{l}\text { Tidak } \\
\text { Diteliti }\end{array}$ & $\begin{array}{l}\text { Tidak } \\
\text { Berpengaruh }\end{array}$ \\
\hline $\begin{array}{l}\text { Kusumawati } \\
\text { dan } \\
\text { Wardhani } \\
(2018)\end{array}$ & $\begin{array}{l}\text { Tidak } \\
\text { Diteliti }\end{array}$ & $\begin{array}{l}\text { Tidak } \\
\text { Diteliti }\end{array}$ & $\begin{array}{l}\text { Berpengaruh } \\
\text { Positif }\end{array}$ \\
\hline
\end{tabular}

Suatu ukuran perusahaan dapat menentukan baik atau tidaknya kinerja dari perusahaan tersebut. Investor biasanya lebih memiliki kepercayaaan pada perusahaan besar. Hal ini dikarenakan perusahaan besar dianggap mampu untuk terus meningkatkan kinerja perusahaannya dengan berupaya meningkatkan kualitas labanya. Perusahaan besar juga dianggap memiliki informasi yang lebih bnayak dibandingkan perusahaan kecil (Mulyani, dkk, 2007). Berdasarkan hal tersebut dan yang menjadi perbedaan penelitian ini dengan penelitian-penelitian sebelumnya adalah penelitian ini inginmenguji apakah ukuran perusahaan dapat dijadikan sebagai variabel pemoderasi pengaruh leverage dan likuiditas terhadap kualitas laba.

Mengingat terdapatnya ketidakkonsistenan antara hasil penelitian tersebut, maka perlu 
ditinjau ulang keterhubungan antara variabelvariabel tersebut dengan kualitas laba. Untuk itulah maka penelitian ini dilakukan. Penelitian ini bertujuan untuk menguji pengaruh leverage, likuiditas, dan ukuran perusahaan terhadap kualitas laba dan menguji keberadaan ukuran perusahaan sebagai variabel pemoderasi pengaruh leverage dan likuiditas terhadap kualitas laba.

\section{RERANGKA TEORITIS}

\section{Teori Agensi}

Di dalam teori agensi, diilustrasikan dua jenis kontrak yang memiliki implikasi bagi teori akuntansi keuangan: kontrak kerja antara perusahaan dan manajer puncaknya dan kontrak pinjaman antara manajer perusahaan dan pemberi pinjaman. Dalam kontak ini pemilik perusahaan sebagai principal manajer puncak sebagai agen (Scott, 2014). Teori agensi adalah sebuah cabang teori permainan yang mempelajari rancangan kontrak untuk memotivasi agen untuk bertindak secara rasional atas nama seorang principal ketika kepentingan agen tersebut bertentangan dengan kepentingan principal (Scott, 2014).

\section{Kualitas Laba}

Memahami kualitas laba merupakan bagian penting dalam memproses dan menafsirkan informasi. Angka laba berkualitas tinggi akan (1) mencerminkan kinerja operasi saat ini, (2) menjadi indikator kinerja operasi masa depan yang baik, (3) dan secara adil menguraikan nilai intrinsik perusahaan (Dechow dan Schrand, 2004).

\section{Leverage}

Posisi hutang perusahaan menunjukkan jumlah uang orang lain yang digunakan untuk menghasilkan keuntungan. Secara umum, semakin banyak hutang yang digunakan perusahaan dalam kaitannya dengan total asetnya, semakin besar pula leverage keuangannya. Leverage keuangan adalah pembesaran risiko dan pengembalian melalui penggunaan pembiayaan biaya tetap, seperti hutang dan saham preferen (Gitman dan Zutter, 2015).

Ada dua jenis ukuran leverage secara umum: mengukur tingkat hutang dan mengukur kemampuan untuk membayar hutang layanan. Tingkat hutang mengukur jumlah hutang relatif terhadap jumlah neraca signifikan lainnya. Dua ukuran populer dari tingkat hutang adalah debt ratio dan debt to equity ratio (Gitman dan Zutter, 2015).

Jenis kedua dari ukuran leverage, kemampuan untuk membayar hutang, mencerminkan kemampuan perusahaan untuk melakukan pembayaran yang diperlukan selama masa hutang. Istilah untuk membayar hutang hanya berarti membayar hutang tepat waktu. Kemampuan perusahaan membayar biaya tertentu tetap diukur dengan menggunakan coverage ratio (Gitman dan Zutter, 2015).

Debt to equity ratio mengukur proporsi relatif dari total kewajiban terhadap ekuitas saham biasa yang digunakan untuk membiayai aset perusahaan. Seperti rasio hutang, semakin tinggi rasio ini, semakin besar pula penggunaan leverage keuangan (Gitman dan Zutter, 2015). 


\section{Likuiditas}

Likuiditas dari sebuah perusahaan diukur dengan kemampuannya untuk memenuhi kewajiban jangka pendeknya saat jatuh tempo. Likuiditas mengacu pada solvabilitas posisi keuangan keseluruhan perusahaan, atau kemudahan untuk membayarnya. Dua ukuran dasar likuiditas adalah current ratio dan quick (acid test ratio) (Gitman dan Zutter, 2015).

Rasio lancar, salah satu rasio keuangan yang paling sering dikutip, mengukur kemampuan perusahaan untuk memenuhi kewajiban jangka pendeknya. Current Ratio adalah Current Asset dibagi Current Liabilities. Rasio arus yang lebih tinggi menunjukkan tingkat likuiditas yang lebih tinggi (Gitman dan Zutter, 2015).

\section{Ukuran Perusahaan}

Dalam Teori Keagenan menyatakan bahwa perusahaan skala besar mempunyai biaya keagenan yang relatif lebih besar dibandingkan dengan perusahaan skala kecil. Ukuran perusahaan didasarkan pada total aset yang dimiliki oleh perusahaan. Perusahaan besar dianggap memiliki informasi yang lebih banyak dibandingkan dengan perusahaan kecil. Perusahaan besar akan mampu mengungkapkan informasi yang lebih banyak dalam rangka untuk mengurangi biaya keagenan. Namun, perusahaan besar juga akan menghadapi risiko politis yang jauh lebih besar dibandingkan dengan perusahaan dengan skala kecil (Kusumawati dan Wardhani, 2018).

Ukuran perusahaan adalah skala besar kecilnya perusahaan yang dapat diklasifikasikan berdasarkan berbagai cara antara lain dengan ukuran pendapatan, total aset, dan total ekuitas (Brigham dan Houston, 2006).

\section{Pengaruh Leverage Terhadap Kualitas \\ Laba}

Leverage digunakan untuk menjelaskan kemampuan perusahaan dalam menggunakan aset dan sumber dana perusahaan. Perusahaan dengan leverage yang tinggi menyebabkan investor beranggapan bahwa perusahaan akan lebih mengutamakan pembayaran hutang daripada dividennya (Darabali dan Saitri, 2016). Berdasarkan penjelasan sebelumya, maka dapat dirumuskan hipotesis penelitian sebagai berikut : $\mathrm{H}_{1}$ : Leverage berpengaruh negatif terhadap kualitas laba.

\section{Pengaruh Likuiditas Terhadap Kualitas}

\section{Laba}

Likuiditas menunjukkan bahwa perusahaan mampu untuk memenuhi kewajiban finansialnya dalam jangka pendek menggunakan dana lancar yang tersedia. Namun apabila likuiditas perusahaan terlalu besar maka perusahaan tersebut tidak mampu mengelola aktiva lancarnya semaksimal mungkin sehingga kinerja keuangan menjadi kurang baik dan kemungkinan ada manipulasi laba untuk mempercantik informasi informasi laba tersebut. Gharezi and Zadeh (2013) dalam Dira dan Astika (2014) menyatakan bahwa likuiditas memiliki hubungan yang lemah dan negatif pada kualitas laba. Berdasarkan penjelasan sebelumya, maka dapat dirumuskan hipotesis penelitian sebagai berikut : 
$\mathrm{H}_{2}$ : Likuiditas berpengaruh negatif terhadap kualitas laba.

\section{Pengaruh Ukuran Perusahaan Terhadap}

\section{Kualitas Laba}

Ukuran perusahaan dinyatakan dengan total aset, jika semakin besar total aset perusahaan maka akan semakin besar pula ukuran perusahaan tersebut. Perusahaan yang memiliki total aset besar menunjukkan bahwa perusahaan tersebut relatif lebih stabil dan mampu menghasilkan laba yang lebih besar dibandingkan perusahaan yang memiliki total aset sedikit atau rendah. Perusahaan yang relatif besar kinerjanya akan dilihat oleh publik sehingga perusahaan tersebut akan melaporkan kondisi keuangannya dengan lebih berhati-hati, lebih menunjukkan keinformatifan informasi yang terkandung di dalamnya dan lebih transparan sehingga perusahaan akan lebih sedikit dalam melakukan manajemen laba. Oleh karena itu, semakin besar ukuran suatu perusahaan memiliki kualitas laba yang lebih tinggi karena tidak perlu melakukan praktik manipulasi laba dan sebaliknya (Warianto dan Rusiti, 2014). Berdasarkan penjelasan sebelumya, maka dapat dirumuskan hipotesis penelitian sebagai berikut :

$\mathrm{H}_{3}$ : Ukuran Perusahaan berpengaruh positif terhadap kualitas laba.

Ukuran Perusahaan sebagai Variabel Pemoderasi Pengaruh Leverage dan Likuiditas Terhadap Kualitas Laba

Variabel moderasi dalam penelitian ini adalah ukuran perusahaan. Variabel moderasi adalah variabel yang mempengaruhi (memperkuat atau memperlemah) hubungan langsung antara variabel bebas dengan variabel terikat (Sugiyono, 2012) .

Ukuran perusahaan merupakan besarnya asset yang dimiliki perusahaan. Perusahaan besar cenderung bertindak hati-hati dalam melakukan pengelolaan perusahaan dan cenderung melakukan pengelolaan laba secara efisien. Perusahaan yang besar lebih diperhatikan oleh masyarakat sehingga mereka akan lebih berhatihati dalam melakukan pelaporan keuangan (Darabali dan Saitri, 2016).

Dalam konteks penelitian ini, peneliti mencoba memoderasikan ukuran perusahaan pada pengaruh leverage dan likuditas terhadap kualitas laba. Dengan demikian, maka dapat dirumuskan hipotesis sebagai berikut :

4 Ukuran perusahaan memoderasi pengaruh leverage dan likuiditas terhadap kualitas laba Berdasarkan hipotesis yang telah dirumuskan, maka model dalam penelitian ini dapat dilihat pada Gambar 1 sebagai berikut

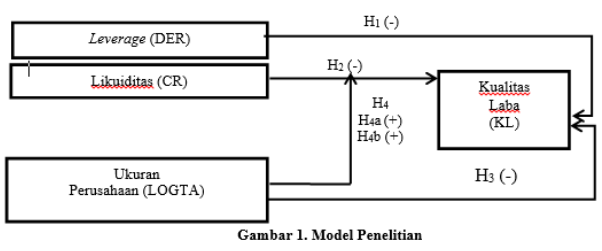

METODE PENELITIAN

\section{Operasionalisasi Variabel Penelitian}

Variabel yang digunakan dalam penelitian ini terdiri dari 2 (dua) jenis, yaitu variabel terikat dan variabel bebas. Kualitas laba bertindak sebagai variabel terikat, sedangkan kesempatan investasi, ukuran perusahaan, leverage, dan likuiditas bertindak sebagai 
variabel bebas. Selengkapnya, operasionalisasi variabel penelitian tersebut dapat dilihat pada Tabel 1.

\section{Metode Pengambilan Sampel}

Populasi dalam penelitian ini adalah perusahaan sektor pertambangan yang tercatat di Bursa Efek Indonesia dalam kurun waktu 20142016. Mengingat tidak semua perusahaan yang tercatat dalam kurun waktu tersebut ada secara konsisten, maka dibentuklah kerangka sampel terlebih dulu. Menurut Indriantoro \& Supomo (2012:120), kerangka sampel merupakan daftar anggota populasi yang relevan untuk dijadikan dasar untuk mengambil sampel.

Kerangka sampel yang dimaksud merupakan perusahaan yang tercatat secara konsisten dalam kurun waktu periode tersebut. Berdasarkan kondisi ini, maka kerangka sampel berjumlah 16 perusahaan. Selanjutnya, jumlah perusahaaan sebagai sampel (S) yang merepresentasi populasi relevan $(\mathrm{N})$ dihitung berdasarkan rumus Slovin dengan batas kesalahan (e) 10\% (Suliyanto, 2009). Adapun rumus Slovin yang dimaksud dapat dilihat pada persamaan (1.1) berikut ini.

$$
S=\frac{N}{1+N^{2}}
$$

Berdasarkan rumus tersebut maka diperoleh $\mathrm{S}$ sebanyak 13,7931 . Nilai ini dibulatkan menjadi 14. Dengan demikian, maka jumlah sampel yang digunakan yaitu 14 perusahaan.

Mengingat populasi bersifat homogen, maka metode pengambilan sampel yang digunakan yaitu metode acak sederhana. Untuk memastikan terjadi proses pengambilan sampel 6 secara acak, maka peneliti menggunakan bantuan angka acak (random) dari Microsoft Excel. Cara ini mengacu pada pernyataan Hartono (2012).

Berdasarkan angka acak, maka 14 nama perusahaan yang terpilih sebagai sampel yaitu: (1) Adaro Energy Tbk. (ADRO), (2) PT Aneka Tambang Tbk (ANTM), (3) Citatah Tbk (CTTH), (4) Elnusa Tbk. (ELSA), (5) Golden Energy Mines Tbk. (GEMS), (7) PT Vale Indonesia Tbk. (INCO), (8) Indo Tambangraya Megah Tbk. (ITMG), (9) Resource Alam Indonesia Tbk. (KKGI), (10) Mitrabara Adiperdana Tbk (MBAP), (11) Samindo Resources Tbk. (MYOH), (12) J Resources Asia Pasifik Tbk., (PSAB), (13) Tambang Batubara Bukit Asam (Persero) Tbk (PTBA), (13) Radiant Utama Interinsco Tbk. (RUIS); (14) Toba Bara Sejahtra Tbk.(TOBA)

\section{Metode Pengumpulan Data}

Metode pengumpulan data dalam penelitian ini menggunakan data arsip. Menurut Hartono (2012), data arsip merupakan data catatan dari sumber yang sudah ada.

\section{Metode Analisis Data}

Metode analisis data yang digunakan yaitu model regresi berganda data pooling. Menurut Ghozali (2016), hasil dari model regresi berupa koefisien untuk masing-masing variabel independen dengan cara memprediksi nilai variabel dependen dalam sebuah persamaan. Adapun model regresi yang dimaksud merupakan model regresi dengan menggunakan variabel interaksi, dimana model tersebut dapat dilihat pada persamaan (1) sebagai berikut. 


$$
\begin{aligned}
\mathrm{KL}_{\mathrm{it}}= & \beta_{0}+\beta_{1} \mathrm{DER}_{\mathrm{it}}+\beta_{2} \mathrm{CR}_{\mathrm{it}}+\beta_{3} \mathrm{LOG}(\mathrm{TA})_{\mathrm{it}}+ \\
& \beta_{4} \mathrm{LOGTAi}_{\mathrm{t}}{ }^{*} \mathrm{DER}_{\mathrm{it}}+\beta_{5} \mathrm{LOG}(\mathrm{TA})_{\mathrm{it}}{ }^{*} \mathrm{CR}_{\mathrm{it}} \\
& +\quad \varepsilon_{\mathrm{it} 1}
\end{aligned}
$$

Untuk menghasilkan model regresi baik secara empirik, maka model regresi ini harus memenuhi serangkaian uji asumsi klasik (Ghozali, 2016). Serangkaian uji asumsi klasik yang dimaksudkan mengacu pada persamaan model regresi pertama. Adapun uji asumsi klasik yang dimaksudkan yaitu sebagai berikut:

1. Uji Normalitas

Uji signifikansi pengaruh variabel independen, terhadap variabel dependen lewat uji t hanya akan valid jika residual model regresi berdistribusi normal (Widarjono, 2009). Dalam penelitian ini, uji normalitas yang digunakan yaitu uji Kolmogorov-Smirnov (KS). Adapun prosedur pengujian normalitas yaitu sebagai berikut.

a. Merumuskan hipotesis nol $\left(\mathrm{H}_{0}\right)$ dan alternatif $\left(\mathrm{H}_{\mathrm{a}}\right)$ :

$\mathrm{H}_{0}$ : Residual $\left(\varepsilon_{\mathrm{it1}}\right)$ berdistribusi normal.

Ha: Residual $\left(\varepsilon_{\mathrm{it} 1}\right)$ tidak berdistribusi normal.

b. Menghitung nilai statistik Z KS dan asymp.sig. (2-tailed)-nya. Untuk menghitung kedua nilai tersebut, maka Program IBM SPSS digunakan mengingat program ini menyediakan informasi mengenai dua nilai tersebut.

c. Menentukan tingkat signifikansi $(\alpha)$. Dalam penelitian ini, nilai $\alpha$ yang dimaksudkan sebesar 5\%.

d. Mengambil kesimpulan statistik dengan membandingkan nilai asymp. sig (2-tailed) atas nilai statistik $\mathrm{Z} \mathrm{KS}$ dengan tingkat signifikansi $(\alpha)$ sebesar $5 \%$ dengan ketentuan:

- Apabila nilai Asymp. Sig. (2-tailed) dari statistik Z KS $\geq$ tingkat signifikansi $(\alpha)$ sebesar $5 \%$, maka $\mathrm{H}_{0}$ diterima.

- Apabila nilai Asymp. Sig (2-tailed) dari statistik $\mathrm{Z} \mathrm{KS}<5 \%$, maka $\mathrm{H}_{0}$ ditolak.

\section{Uji Autokorelasi}

Uji autokorelasi bertujuan menguji apakah ada ada korelasi antara kesalahan penggangu pada periode $\mathrm{t}$ dengan kesalahan pengganggu pada periode t-1 (sebelumnya). Jika terjadi korelasi, maka dinamakan ada. problem autokorelasi. Hal ini muncul karena observasi yang berurutan sepanjang waktu berkaitan satu sama lainnya. Masalah ini timbul karena residual (kesalahan pengganggu) tidak bebas dari satu observasi ke observasi lainnya (Ghozali, 2016). Dalam penelitian ini, pengujian autokorelasi dilakukan dengan menggunakan uji runs atas nilai residual dengan prosedur sebagai berikut. Pertama, membuat hipotesis nol dan alternatif: $\mathrm{H}_{0}$ : Tidak terdapat autokorelasi (residual acak). Ha: Terdapat autokorelasi (residual tidak acak) Kedua, dengan menggunakan program IBM SPSS, perhitungan nilai Asymp. Sig (2tailed) atas Z-statistik dilakukan. Langkah ketiga, menentukan tingkat signifikansi $(\alpha)$ sebesar 5\%. Langkah keempat, nilai Asymp. Sig (2-tailed) atas Z-statistik dibandingkan dengan $\alpha$ sebesar 5\% sebagai dasar pengambilan keputusan penerimaan hipotesis nol atau alternatif dengan ketentuan sebagai berikut. Jika nilai asymp. sig (2-tailed) atas Z-statistik lebih besar daripada $\alpha$ sebesar 5\%, maka hipotesis 
alternatif ditolak sehingga tidak terdapat autokorelasi, dan sebaliknya.

\section{Uji Heteroskedastisitas}

Uji heteroskedastisitas bertujuan menguji apakah dalam model regresi terjadi ketidaksamaan variance dari residual satu pengamatan ke pengamatan lainnya. Jika varian dari satu pengamatan ke pengamatan lain tetap, maka disebut homokedastisitas dan jika berbeda disebut heterokedastisitas. Model regresi yang baik adalah yang homokedastisitas atau yang tanpa heterokedastisitas (Ghozali, 2016). Uji heteroskedastisitas dalam penelitian ini menggunakan uji White. Adapun prosedur pengujiannya yaitu dengan merumuskan hipotesis nol $\left(\mathrm{H}_{0}\right)$ dan hipotesis alternatif $(\mathrm{Ha})$ sebagai berikut:

$\mathrm{H}_{0}$ : Tidak terdapat heteroskedastisitas (tidak satupun variabel bebas yang dikuadratkan berpengaruh terhadap varian error).

Ha: Terdapat heteroskedastisitas (sekurangkurangnya terdapat satu variabel bebas yang dikuadratkan yang berpengaruh terhadap varian error).

Uji White dapat dilakukan dengan meregres residual yang dikuadratkan $\left(\varepsilon_{\mathrm{it} 1}\right)$ dengan variabel independen yang dikuadratkan (Ghozali, 2016). Berdasarkan penjelasan tersebut, maka dalam penelitian ini dapatlah dijabarkan persamaan regresi sebagai berikut:

$$
\begin{aligned}
& \varepsilon_{\mathrm{it1}}^{2}=\gamma_{0}+\gamma_{1} \cdot \mathrm{DER}_{\mathrm{it}}{ }^{\wedge}+\gamma_{2} \cdot \mathrm{CR}_{\mathrm{it}}{ }^{\wedge}+ \\
& \gamma_{3} \cdot \operatorname{LOG}(\mathrm{TA})_{\mathrm{it}} \wedge 2 \\
& \gamma 4 . \text { LOGTAi }_{\mathrm{t}}{ }^{\wedge} 2 * \mathrm{DER}_{\mathrm{it}} \wedge 2 \\
& \gamma_{5} \cdot \operatorname{LOG}(\mathrm{TA})_{\mathrm{it}}{ }^{\wedge} 2 * \mathrm{CR}_{\mathrm{it}} \quad{ }^{\wedge}+\varepsilon_{\mathrm{it} 2}
\end{aligned}
$$

Dari persamaan regresi tersebut diatas, akan didapat nilai probabilitas Chi-Square atas Obs* $\mathrm{R}^{2}$ dengan menggunakan program EVIEWS. Selanjutnya, nilai tersebut dibandingkan dengan $\alpha$ sebesar 5\% Jika nilai probabilitas dari Chi-Square atas Obs* $\mathrm{R}^{2}$ lebih besar daripada $\alpha$ sebesar 5\%, maka hipotesis alternatif ditolak sehingga tidak terdapat heteroskedastisitas dalam model regresi.

\section{Pengujian Hipotesis Penelitian}

Untuk dapat diuji, hipotesis penelitian harus diterjemahkan terlebih dulu menjadi hipotesis statisitik yang meliputi hipotesis nol $\left(\mathrm{H}_{0}\right)$ dan hipotesis alternatif (Ha). Untuk hipotesis penelitian pertama, hipotesis nol dan alternatif yang dimaksudkan yaitu sebagai berikut:

$\mathrm{H}_{01}: \beta_{1} \geq 0$ : Leverage berpengaruh positif atau tidak berpengaruh terhadap kualitas laba.

$\mathrm{Ha}_{1}: \beta_{1}<0: \quad$ Leverage berpengaruh negatif terhadap kualitas laba.

Untuk hipotesis penelitian kedua, hipotesis nol dan alternatif yang dimaksudkan yaitu sebagai berikut:

$\mathrm{H}_{02}: \beta_{2} \geq 0$ : Likuiditas berpengaruh positif atau tidak berpengaruh terhadap kualitas laba.

$\mathrm{Ha}_{2}: \beta_{2}<0: \quad$ Likuiditas berpengaruh negatif terhadap kualitas laba.

Untuk hipotesis penelitian ketiga, hipotesis nol dan alternatif yang dimaksudkan yaitu sebagai berikut:

$\mathrm{H}_{03}: \beta_{3} \leq 0$ : Ukuran perusahaan berpengaruh negatif atau tidak berpengaruh terhadap kualitas laba. 
$\mathrm{Ha}_{3}: \beta_{3}>0: \quad$ Ukuran perusahaan berpengaruh positif terhadap kualitas laba.

Untuk hipotesis penelitian keempat, hipotesis nol dan alternatif yang dimaksudkan yaitu sebagai berikut:

$\mathrm{H}_{04}: \beta_{4}, \beta_{5} \leq 0$ : Tidak ada efek interaksi yang berpengaruh terhadap kualitas laba.

$\mathrm{Ha}_{4}$ : Sekurang-kurangnya terdapat satu nilai $\beta$ (dari $\beta_{4}$ dan $\left.\beta_{4}\right) \neq 0$ : Sekurang kurangnya terdapat satu efek interaksi yang berpengaruh terhadap kualitas laba.

Untuk hipotesis penelitian $4 \mathrm{a}$, hipotesis nol dan alternatif yang dimaksudkan yaitu sebagai berikut:

$\mathrm{H}_{04} \mathrm{a}: \beta_{4} \leq 0$ : Efek interaksi ukuran perusahaan dengan leverage berpengaruh negatif atau tidak berpengaruh terhadap kualitas laba.

$\mathrm{Ha}_{4} \mathrm{a}: \beta_{4}>0$ : Efek interaksi ukuran perusahaan dengan leverage berpengaruh positif terhadap kualitas laba.

Untuk hipotesis penelitian $4 \mathrm{~b}$, hipotesis nol dan alternatif yang dimaksudkan yaitu sebagai berikut:

$\mathrm{H}_{04} \mathrm{~b}: \beta_{5} \leq 0: \quad$ Efek interaksi ukuran perusahaan dengan likuiditas berpengaruh negatif atau tidak berpengaruh terhadap kualitas laba.

$\mathrm{Ha}_{4} \mathrm{~b}: \beta_{5}>0$ : Efek interaksi ukuran perusahaan dengan likuiditas berpengaruh positif terhadap kualitas laba.

Langkah kedua yaitu perhitungan nilai tstatistik dan probabilitas atas t-statistik atas setiap nilai koefisien regresi. Perhitungan nilai tstatistik ini dilakukan dengan menggunakan program E-Views. Langkah ketiga, menetapkan tingkat signifikansi $(\alpha)$ yang digunakan. Dalam penelitian ini, tingkat signifikansi yang digunakan yaitu 5\%. Langkah keempat, mengambil keputusan penolakan hipotesis nol dengan mengacu pada ketentuan sebagai berikut.

- Jika nilai probabilitas dari t-statistik atas variabel bebas yang digunakan $\geq$ tingkat signifikansi $(\alpha)$ sebesar $5 \%$, maka $\mathrm{H}_{0}$ diterima.

- Jika nilai probabilitas dari t-statistik atas variabel bebas yang digunakan $<\alpha$ sebesar $5 \%$, maka $\mathrm{H}_{0}$ ditolak.

Untuk melakukan pengujian tentang keberadaan ukuran perusahaan sebagai variabel moderasi maka peneliti menggunakan uji penambahan variabel bebas dalam model penelitian. Model regresi ini dibuat sebelum dan setelah memasukkan variabel moderasi. Adapun model regresi sebelum efek interaksi ditambahkan dalam dapat dilihat pada persamaan di bawah ini:

$\mathrm{KL}_{\mathrm{it}}=\theta_{0}+\theta_{1} \cdot \mathrm{DER}_{\mathrm{it}}+\theta_{2} \cdot \mathrm{CR}_{\mathrm{it}}+\theta_{3} \cdot \operatorname{LOG}(\mathrm{TA})_{\mathrm{it}}+$ $\varepsilon_{\mathrm{it} 0}$

sedangkan model regresi setelah efek interaksi ditambahkan dapat dilihat pada persamaan 1 seperti yang dinyatakan pada bagian sebelumnya. Adapun model regresi pada persamaan 1 sebagai berikut.

$\mathrm{KL}_{\mathrm{it}}=\beta_{0}+\beta_{1} \cdot \mathrm{DER}_{\mathrm{it}}+\beta_{2} \cdot \mathrm{CR}_{\mathrm{it}}+\beta_{3} \cdot \mathrm{LOG}(\mathrm{TA})_{\mathrm{it}}+$

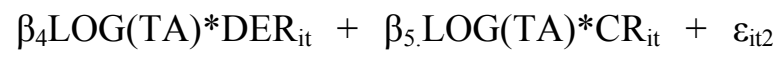

Uji ini dilakukan dengan menggunakan teknik restriksi, yaitu dengan membuat model dengan restriksi $[\mathrm{KL}=\mathrm{f}(\mathrm{DER}, \mathrm{CR}, \mathrm{LOG}(\mathrm{TA}))]$ dan tanpa restriksi $[\mathrm{KL}=\mathrm{f}(\mathrm{DER}, \quad \mathrm{CR}$, LOG(TA),LOG(TA)*DER,LOG(TA)*CR)]Uji 
ini menurut Widarjono (2009) dilakukan dengan membandingkan nilai probabilitas F-statisik setelah dimasukkannya variabel interaksi LOG_TA*DER dan LOG_TA*CR pada persamaan (1) dengan tingkat $\alpha$ sebesar 5\% dengan ketentuan sebagai berikut :

- Apabila nilai probabilitas F-statistik lebih besar dari a sebesar 5\%, maka penambahan variabel bebas tidak memiliki pengaruh yang signifikan.

- Apabila nilai probabilitas F-statistik kurang dari a sebesar 5\%, maka penambahan variabel bebas tersebut signifikan. Hal ini berarti ukuran perusahaan memoderasi pengaruh leverage dan likuiditas terhadap kualitas laba.

\section{HASIL PENELITIAN DAN PEMBAHASAN}

\section{Hasil Uji Asumsi Klasik}

\section{a. Hasil Uji Normalitas}

Uji normalitas yang digunakan yaitu uji Komogorov-Smirnov atas nilai residual model penelitian yang pertama. Selengkapnya, hasil uji normalitas dapat dilihat pada Tabel 2. Pada tabel tersebut, terlihat Asymp.Sig (2-tailed) sebesar 0,321 . Mengingat nilai lebih besar dari pada $\alpha$ sebesar 5\%, maka hipotesis nol diterima. Dengan demikian, residual model regresi berdistribusi normal.

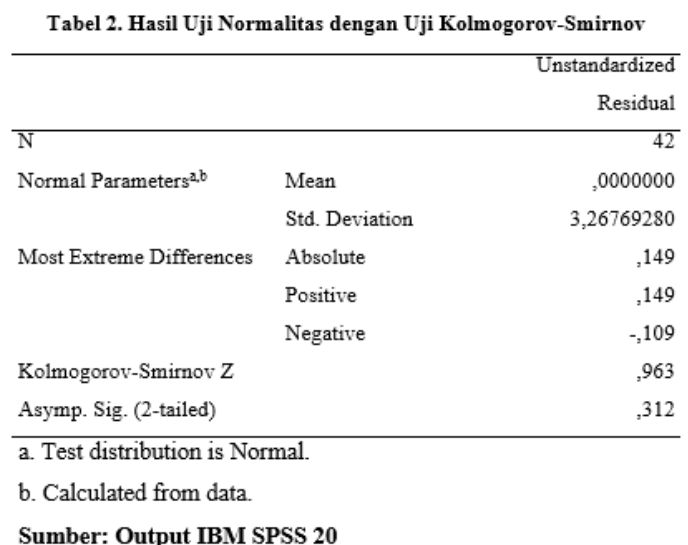

b. Uji Autokorelasi

Uji autokorelasi yang digunakan dalam penelitian ini yaitu uji runs. Uji ini dilakukan dengan membandingkan nilai asymp.sig.(2tailed) dari $\mathrm{Z}$ dengan tingkat signifikansi $(\alpha)$ sebesar 5\%. Selengkapnya hasil uji run dapat dilihat pada Tabel 3 .

\begin{tabular}{lr}
\multicolumn{2}{c}{ Tabel 3. Hasil Uji Autokorelasi dengan Uji Runs } \\
\hline & Unstandardized Residual \\
\hline Test Value ${ }^{2}$ & 0,0000000 \\
Cases < Test Value & 27 \\
Cases >= Test Value & 15 \\
Total Cases & 42 \\
Number of Runs & 18 \\
Z & $-0,609$ \\
Asymp. Sig. (2-tailed) & 0,543 \\
\hline a. Mean & \\
Sumber: Output IBM SPSS20.
\end{tabular}

Terlihat pada tabel tersebut nilai asymp.sig.(2tailed) dari $\mathrm{Z}$ sebesar 0,543 . Mengingat nilai ini lebih besar dari $\alpha$ yang ditetapkan sebesar 5\%, maka $\mathrm{H}_{0}$ diterima. Dengan demikian, maka residual acak sehingga $\mathrm{H}_{0}$ diterima sehingga tidak terjadi autokorelasi dalam model regresi ini.

\section{c. Hasil Uji Heteroskedastisitas}

Uji heteroskedastistitas yang digunakan dalam penelitian ini yaitu uji White. Uji ini dilakukan dengan membandingkan nilai Prob.ChiSquare(5) atas Obs*R-square dengan tingkat 
signifikansi $(\alpha)$ sebesar 5\%. Selengkapnya hasil uji White dapat dilihat pada Tabel 4. Pada tabel tersebut, terlihat nilai Prob.Chi-Square(5) atas $O b s * R$-square sebesar 0,3729 . Mengingat nilai ini lebih besar dari $\alpha$ yang ditetapkan sebesar 5\%, maka $\mathrm{H}_{0}$ diterima. Dengan demikian, maka tidak terjadi heteroskedastisitas dalam model regresi ini

\begin{tabular}{|c|c|c|c|c|}
\hline F-statistic & 1,054543 & Prob. $F(5,36)$ & & 0,4014 \\
\hline Obs*R-squared & 5,365629 & Prob. Chi-Squ & e(5) & 0,3729 \\
\hline Scaled explained SS & 10,67264 & Prob. Chi-Squ & e(5) & 0,0583 \\
\hline \multicolumn{5}{|l|}{ Test Equation: } \\
\hline \multicolumn{5}{|c|}{ Dependent Variable: RESID $/ 2$} \\
\hline \multicolumn{5}{|l|}{ Method: Least Squares } \\
\hline \multicolumn{5}{|c|}{ Date: $12 / 18 / 17$ Time: $09: 13$} \\
\hline \multicolumn{5}{|c|}{ Sample: $1913 \quad 15 \quad 19454951$} \\
\hline \multicolumn{5}{|c|}{ Included observations: 42} \\
\hline Variable & Coefficient & Std. Error & t-Statistic & Prob. \\
\hline $\mathrm{C}$ & -22.49721 & 37.71941 & -0.596436 & 0.5546 \\
\hline $\operatorname{LOGTA}^{\wedge} 2$ & 0.134776 & 0.153379 & 0.878715 & 0.3854 \\
\hline $\mathrm{DER} / 2$ & 13.55413 & 11.10714 & 1.220308 & 0.2303 \\
\hline $\mathrm{CR}^{\wedge} 2$ & -0.000162 & 0.000528 & -0.305762 & 0.7615 \\
\hline$(\mathrm{DER} * \mathrm{LOGTA})^{\wedge} 2$ & -0.059359 & 0.059845 & -0.991879 & 0.3279 \\
\hline$(\mathrm{CR} * \text { LOGTA })^{\wedge} 2$ & $5.23 \mathrm{E}-07$ & $2.04 \mathrm{E}-06$ & 0.256455 & 0.7991 \\
\hline
\end{tabular}

\section{Hasil Pengujian Hipotesis Penelitian}

Pengujian semua hipotesis penelitian ini mengacu pada koefisien regresi yang terdapat pada model tanpa restriksi (model setelah efek interaksi ditambahkan ke dalam model penelitian). Hipotesis penelitian pertama menyatakan leverage berpengaruh negatif terhadap kualitas laba. Hipotesis ini diuji dengan membandingkan nilai probabilitas t-statistik atas koefisien regresi DER dengan $\alpha$ sebesar 5\%, Terlihat pada Tabel 5, probabilitas tersebut bernilai sebesar 0,0000 . Mengingat nilai tersebut lebih kecil dari pada $\alpha$ sebesar 5\% maka hipotesis alternatif diterima. Dengan demikian, leverage berpengaruh negatif secara signifikan terhadap kualitas laba.

Hipotesis penelitian kedua menyatakan likuiditas berpengaruh negatif terhadap kualitas laba. Hipotesis ini diuji dengan membandingkan nilai probabilitas t-statistik atas koefisien regresi CR dengan $\alpha$ sebesar 5\%, Terlihat pada Tabel 5, probabilitas tersebut bernilai sebesar 0.0037 . Mengingat nilai tersebut lebih kecil dari pada $\alpha$ sebesar 5\%, maka hipotesis alternatif diterima. Dengan demikian, likuiditas berpengaruh negatif secara signifikan terhadap kualitas laba.

Hipotesis penelitian ketiga menyatakan ukuran perusahaan berpengaruh negatif terhadap kualitas laba. Hipotesis ini diuji dengan membandingkan nilai probabilitas t-statistik atas koefisien regresi LOGTA dengan $\alpha$ sebesar 5\%. Terlihat pada Tabel 5, probabilitas tersebut bernilai sebesar 0,0008. Mengingat nilai tersebut lebih kecil dari pada a sebesar 5\%, maka hipotesis alternatif yang diterima. Dengan demikian, ukuran perusahaan berpengaruh negatif secara signifikan terhadap kualitas laba.

Hipotesis penelitian keempat menyatakan ukuran perusahaan memoderasi pengaruh leverage dan likuiditas terhadap kualitas laba. Hipotesis ini diuji dengan membandingkan nilai probabilitas F-statistik $(2,36)$ dengan $\alpha$ sebesar 5\%. Terlihat pada Tabel 5, probabilitas tersebut bernilai sebesar 0,0001. Mengingat nilai tersebut lebih kecil dari pada $\alpha$ sebesar 5\%, maka hipotesis alternatif yang menyatakan sekurang-kurangnya terdapat satu efek interaksi yang berpengaruh pada kualitas laba dapat diterima. Dengan demikian ukuran perusahaan dapat berfungsi sebagai variabel pemoderasi. 
Hipotesis 4a menyatakan efek interaksi ukuran perusahaan dengan leverage berpengaruh positif terhadap kualitas laba. Hipotesis ini diuji dengan membandingkan nilai probabilitas $\mathrm{t}$ statistik atas koefisien regresi LOGTA*DER dengan $\alpha$ sebesar 5\%. Terlihat pada Tabel 5, probabilitas tersebut bernilai sebesar 0,0000 . Mengingat nilai tersebut lebih kecil dari pada $\alpha$ sebesar 5\%, maka hipotesis alternatif yang diterima. Dengan demikian, efek interaksi ukuran perusahaan dengan leverage berpengaruh posiif secara signifikan terhadap kualitas laba. Hipotesis 4b menyatakan efek interaksi ukuran perusahaan dengan likuiditas berpengaruh positif terhadap kualitas laba. Hipotesis ini diuji dengan membandingkan nilai probabilitas t-statistik atas koefisien regresi LOGTA*CR dengan $\alpha$ sebesar 5\%. Terlihat pada Tabel 5, probabilitas tersebut bernilai sebesar 0,0028 . Mengingat nilai tersebut lebih kecil dari pada $\alpha$ sebesar 5\%, maka hipotesis alternatif yang diterima. Dengan demikian, efek interaksi ukuran perusahaan berpengaruh positif secara signifikan terhadap kualitas laba.

\section{Pembahasan}

Hasil pengujian hipotesis pertama, diperoleh hasil bahwa leverage berpengaruh negatif secara signifikan terhadap kualitas laba.

Hasil pengujian hipotesis kedua, likuiditas berpengaruh negatif secara signifikan terhadap kualitas laba. Hasil penelitian ini mendukung hasil penelitian yang dilakukan oleh Warianto dan Rusiti (2014). Current ratio yang tinggi biasanya dianggap menunjukkan tidak terjadi masalah dalam likuiditas, sehingga semakin tinggi likuiditas artinya laba yang dihasilkan perusahaan berkualitas karena 12 manajemen perusahaan tidak perlu melakukan manajemen laba (Warianto dan Rusiti, 2014 : 20). Dengan demikian, tingkat likuiditas yang tinggi menunjukkan laba yang dihasilkan perusahaan berkualitas.

Hasil pengujian hipotesis ketiga, ukuran perusahaan berpengaruh negatif secara signifikan terhadap kualitas laba. Hasil penelitian ini mendukung hasil penelitian yang dilakukan oleh Warianto dan Rusiti (2014).

Hasil pengujian hipotesis keempat menunjukkan bahwa ukuran perusahaan dapat menjadi variabel pemoderasi. Untuk mengetahui variabel yang dapaat dimoderasi pengaruhnya oleh ukuran perusahaan, maka pengujian hipotesis $4 \mathrm{a}$ dan $4 \mathrm{~b}$ menjadi sangat penting untuk dilakukan.

- Berdasarkan pengujian hipotesis 4a, diperoleh hasil bahwa efek interaksi ukuran perusahaan dengan leverage berpengaruh positif secara signifikan terhadap kualitas laba. Hal ini berarti leverage berpengaruh negatif terhadap kualitas laba ketika ukuran perusahaan semakin besar.

Berdasarkan pengujian hipotesis $4 \mathrm{~b}$, diperoleh hasil bahwa efek interaksi ukuran perusahaan dengan likuditas berpengaruh positif secara signifikan terhadap kualitas laba. Hal ini berarti likuiditas berpengaruh negatif terhadap kualitas laba ketika ukuran perusahaan semakin besar. 


\section{SIMPULAN DAN SARAN}

\section{Simpulan}

Berdasarkan hasil pembahasan, maka terdapat beberapa hal yang dapat disimpulkan sebagai berikut. Pertama, leverage berpengaruh negatif terhadap kualitas laba. Kedua, likuiditas berpengaruh negatif terhadap kualitas laba. Ketiga, ukuran perusahaan berpengaruh negatif terhadap kualitas laba. Keempat, ukuran perusahaan bertindak sebagai variabel pemoderasi pengaruh leverage dan likuiditas berpengaruh negatif terhadap kualitas laba.

\section{Saran}

Saran dalam penelitian ini adalah :

1. Untuk mendapatkan perusahaan dengan kualitas laba yang baik, maka investor memilih perusahaan dengan leverage dan likuiditas yang kecil.

2. Untuk peneliti selanjutnya sebaiknya menggunakan ukuran lain seperti kepemilikan institusional, kepemilikan manajerial, dan investment opportunity set untuk melihat pengaruhnya terhadap kualitas laba.

3. Untuk peneliti selanjutnya sebaiknya dapat menggunakan pengukuran kualitas laba yang lain.

\section{DAFTAR PUSTAKA}

Abdelghany, K.E.M. 2005. Measuring The Quality of Earnings. Managerial Auditing Journal. 20: 1001-1015.

Ahalik \& Y. Hardy. 2015. The Impact of IFRS Implementation, Leverage, Audit Quality, Institusional Ownership, and Managerial Ownership Towards Earnings Quality of Indonesian Listed Companies in LQ-45. IJABER, 13(1): 183-199.

Bellovery, J.L., D.E. Giacomino, \& M.D. Akers. 2005. Earnings Quality: It's Time to Measure and Report. The CPA Journal 75(11): 32-37.

Brigham, F.E. dan J.F. Houston. 2006. DasarDasar Manajemen Keuangan. Edisi 10. Penerbit Salemba Empat. Jakarta.

Darabali, P.M., \& P.W. Saitri. 2016. Analisis Faktor-Faktor yang Mempengaruhi Kualitas Laba Pada Perusahaan Manufaktur di Bursa Efek Indonesia Tahun 2010-2013. Jurnal Riset Akuntansi Juara 6(1): 46-60.

Dechow P.M. dan C.M. Schrand. 2004. Earnings Quality. Research Foundation Publications, 3:1-152.

Dechow, P., W. Ge, \& C. Schrand. 2010. Understanding Earnings Quality: A Review of The Proxies, Their Determinants and Their Consequences. Journal of Accounting and Economics 50: 344-401.

Dira, K.P \& I.B.P. Astika. 2014. Pengaruh Struktur Modal, Likuiditas, Pertumbuhan Laba, dan Ukuran Perusahaan Pada Kualitas Laba. E-Jurnal Akuntansi Universitas Udayana 7.1: 64-78.

Fauzi, A.K., E. Pituringsih dan B.A. Inapty. 2015. Determinan yang Mempengaruhi Kualitas Laba Pada Perusahaan Manufaktur di Indonesia (Analisis Sebelum dan Sesudah Adopsi IFRS). Jurnal Riset Akuntansi Mercu Buana 1(2): 113-137. 
Ghozali, I. 2016. Aplikasi Analisis Multivariat dengan Program IBM SPSS 23. Edisi Kedelapan. Semarang: Badan Penerbit Universitas Diponegoro.

Gitman, L.J. dan C.J. Zutter. 2015. Principles of Managerial Finance. Fourteenth Edition. Pearson .

Hartono, J. 2012. Metodologi Penelitian Bisnis: Salah Kaprah dan PengalamanPengalaman. Edisi Kelima. Cetakan Pertama. Yogyakarta: BPFE-UGM.

Indriantoro, N. dan B. Supomo. 2002. Metodologi Penelitian Bisnis Untuk Akuntansi \& Manajemen. Yogyakarta: BPFE-UGM.

Kartina, E. \& Nikmah. 2011. Pengaruh Corporate Governance, Investment Opportunity Set (IOS) Terhadap Kualitas Laba dan Nilai Perusahaan. Jurnal Akuntansi 1(1): 92-121.

Kurniawati. 2017. Pengaruh Mekanisme Good Corporate Governance, Set Kesempatan (IOS) dan Ukuran Perusahaan Terhadap Kualitas Laba. Jurnal Akuntansi Bisnis 9(2): 240-258.

Kusumawati, H. \& S.L. Wardhani. 2018. Analisis Determinan yang Mempengaruhi Kualitas Laba Studi Pada Perusahaan Manufaktur Di Bursa Efek Indonesia (Periode 2012-2016). MODUS 30(I) : 1737.

Mulyani. S., N.F. Asyik., \& Andayani. 2007. Faktor-Faktor yang Mempengaruhi Earnings Response Coefficient Pada Perusahaan yang Terdaftar di Bursa Efek Jakarta. Skripsi yang tidak dipublikasikan STIESA, Surabaya.

Reyhan A., Zirman. \& Nurazlina. 2014. Pengaruh Komite Audit, Asimetri Informasi, Ukuran Perusahaan, Pertumbuhan Laba Dan Profitabilitas Terhadap Kualitas Laba (Studi Pada Perusahaan Manufaktur yang Terdaftar di BEI 2009-2010). JOM FEKON 1(2): 1-17.

Scott, W.R. 2014. Financial Accounting Theory. $7^{\text {th }}$ edition. Pearson. Toronto.
Warianto P., \& C. Rusiti. 2014. Pengaruh Ukuran Perusahaan, Struktur Modal, Likuiditas, dan Investment Opportunity Set (IOS) Terhadap Kualitas Laba Pada Perusahaan Manufaktur yang Terdaftar di BEI. Modus 26(1): 19-32.

Sugiyono. 2012. Metode Penelitian Kuantitatif, Kualitatif dan Kombinasi (Mixed Method. Penerbit Alfabeta. Bandung.

Suliyanto. 2009. Metode Riset Bisnis. CV Andi Offset.Yogyakarta.

4. Widarjono, A. 2009. Ekonometrika: Pengantar dan Aplikasinya. Edisi Ketiga. Cetakan Pertama. Penerbit Ekonesia. Yogyakarta. 